\title{
Case report of a rare case of Non-hodgkin Lymphoma presenting as sternal mass
}

\author{
Konwar N. ${ }^{1}$, Dutta A. ${ }^{2}$, Sharma A. ${ }^{3}$, Saikia P. ${ }^{4}$ \\ ${ }^{1}$ Dr. Nilotpal Konwar, Post Graduate Trainee, ${ }^{2}$ Dr. Aparna Dutta, Assistant Professor, ${ }^{3}$ Dr. Adity Sharma, \\ Professor, ${ }^{4}$ Dr. Projnan Saikia, Professor and Head, all authors are affiliated with Department of Pathology, \\ Assam Medical College and Hospital, Dibrugarh, Assam, India.
}

Address for Correspondence: Dr. Nilotpal Konwar, Post Graduate Trainee, Department of Pathology, Assam Medical College and Hospital, Dibrugarh, Assam. Email id: nilotpal.kon@gmail.com, nilkon77@gmail.com

\begin{abstract}
Primary or metastatic tumors of the chest wall constitute 5\% of all thoracic tumors and lymphoma comprises about $2 \%$ of all chest wall tumors. We report a case of a 23 year old male presenting with anterior chest wall mass for the past 6 months which was slowly growing in size. There was no other symptoms of respiratory difficulty, cough, and hemoptysis. HRCT chest revealed soft tissue attenuated lesion in mid chest wall and infiltration to the anterior mediastinum with erosion of sternum and the $8^{\text {th }}$ rib. FNAC of the site revealed NonHodgkin Lymphoma. Diagnosis is based on morphological features, FNAC, cell block.
\end{abstract}

Keywords: Chest wall mass, Lymphoma, FNAC

\section{Introduction}

The Non-Hodgkin lymphomas are a large group of heterogeneous clonal lymphoid neoplasms. Their clinical presentation and natural history is much more variable than Hodgkin Lymphoma. NHL usually originates in the nodal tissues but its predilection for extranodal tissue is higher than Hodgkin Lymphoma. NHL varies from some being very indolent and the others being very aggressive [1]. 5\% of all thoracic tumors are primary or metastatic tumors and lymphoma comprises about $2 \%$ of all chest wall tumors [2, 3]. Chest wall tumors are rare. Chest wall destruction due to an anterior mediastinal mass, or a chest wall tumor associated with mediastinal lymph node enlargement, could be suspicious of thoracic lymphoma. Poorly differentiated tumors have more bone involvement than well differentiated one. Mediastinal adenopathy occurs frequently in Hodgkin's disease but is unusual in non-Hodgkin's lymphoma, in which endobronchial and diffuse interstitial involvement occur. Isolated chest wall masses are distinctly uncommon and are usually manifestation of large cell Non-Hodgkin's lymphoma.

\section{Case Report}

A 23 years old male presented with anterior chest wall mass for the past 6 months which was slowly growing in size. There was no other symptoms of respiratory difficulty, cough, and hemoptysis. He complained of fever 10 days back. His family history and history of past illness was insignificant. On general physical examination the patient was average built, ill looking. On local examination a mass of size $3.5 \times 2.5 \mathrm{~cm}$ was present in the mid anterior chest wall over the manubrium sterni. It was fixed, tender, firm and locally inflamed. There was no hepatosplenomegaly, no palpable lymph nodes present, and no icterus. His respiratory system examination, GIT system examination, Cardiovascular system was normal. His blood count showed mild leukocytosis $\left(12 \times 10^{9} / \mathrm{L}\right)$, was mild anemic (12.6g/dl), ESR was well within the range, BP was 130/88 mm of $\mathrm{Hg}$, Pulse rate 88/min, Mild fever was present. Routine urine examination revealed normal values of protein, sugar, creatine, uric acid, and

Manuscript received: $30^{\text {th }}$ October 2017

Reviewed: $8^{\text {th }}$ November 2017

Author Corrected: $17^{\text {th }}$ November 2017

Accepted for Publication: $23^{\text {rd }}$ November 2017 


\section{Case Report}

bilirubin. HRCT chest revealed soft tissue attenuated lesion in mid chest wall and infiltration to the anterior mediastinum with erosion of sternum and the $8^{\text {th }}$ rib.USG of abdomen, CT pelvis was normal. FNAC of the site revealed Non-Hodgkin Lymphoma. Cell block from the site was taken which confirmed the diagnosis of NonHodgkin Lymphoma. IHC was done on the cell block which revealed the diagnosis of NHL with positivity for CD45, CD20. The patient was sent to B. Barooh Cancer Institute (Higher Referral Centre) for further management as surgical excision was considered high risk here.

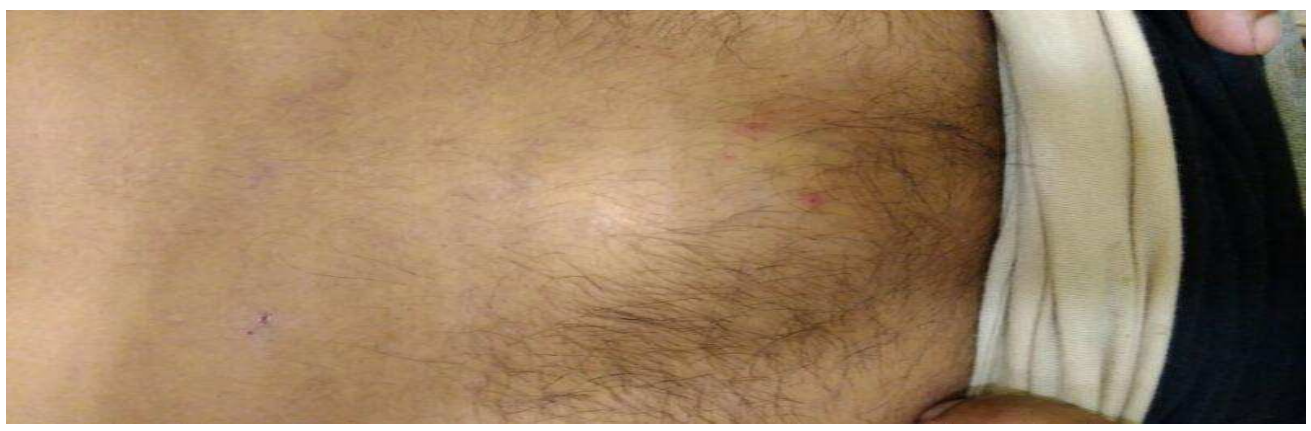

Figure 1: Swelling over the chest of the patient.

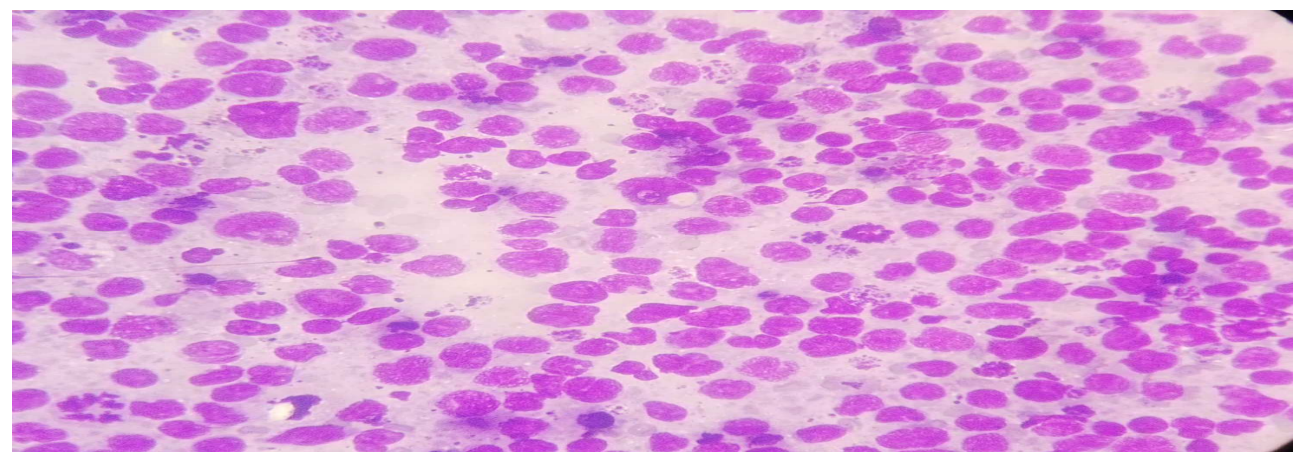

Figure 2: Low power (10X) field of FNAC showing monomorphic population of malignant lymphoid cells in a background of lymphoglandular bodies

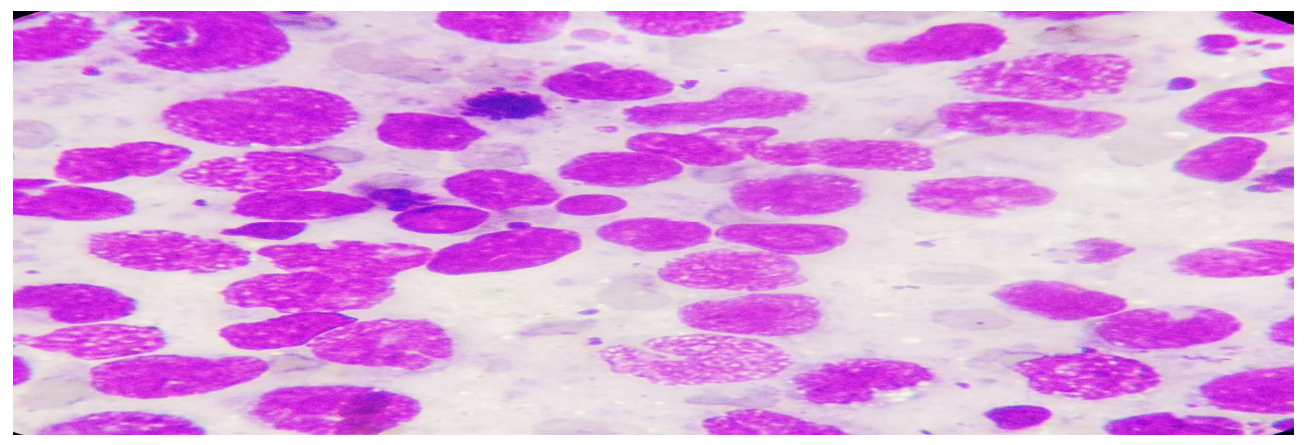

Figure 3: High power (40X) view of FNAC showing monomorphic population of malignant lymphoid cells with some showing prominent nucleoli.

\section{Discussion}

Lymphoma involves the chest wall in $10-15 \%$ of patients. It constitutes $3-5 \%$ of primary malignant bone tumours. The commonest being the NonHodgkin Lymphoma (94\%) [4]. Only few cases of Non-Hodgkin lymphoma of the sternum have been reported in the literature till now. Most of the cases of anterior chest wall lymphoma reported have either been associated with metastasis or direct invasion from the anterior mediastinum. Only a few have been reported as primary in the anterior chest wall. Initially FNAC was done which showed the picture of Non-Hodgkin lymphoma. Diagnosis was confirmed by cell block preparation and subsequent IHC. Although diagnostic efficacy of FNAC for 


\section{Case Report}

determination of primary chest wall tumor has not yet being determined $[5,6,7,8]$ but with adequate aspirate and use of another modalities cell blocking and IHC help to come to a conclusion of NHL. Many authors suggested that the tumours with Primary chest wall mass should have at least excision biopsy [9-13]. Our patient was send for further management to a higher and well equipped institute. Although lymphoma patients are usually treated with local irradiation and chemotherapy, but resection of chest wall lymphoma as primary site is still undetermined. Studies have found that patients with chest wall invasion has poor local control and survival [14].

\section{Conclusion}

Sternal lymphoma presenting as chest wall mass is a rare entity comprising of only $2 \%$ of the chest wall tumours. Absence of pulmonary symptoms with only mild chest discomfort suggests the confinement of the tumor to the chest wall and the adjoining tissue. Diagnostic efficacy of FNAC was accurate with the adjunct of cell block and IHC. Patient was later sent for final diagnosis and treatment to higher referral Centre for further management.

\section{Funding: Nil, Conflict of interest: None Permission of IRB: Yes}

\section{References}

1. Hoffbrand essential haematology, $7^{\text {th }}$ edition

2. Witte B, Hürtgen M. Lymphomas presenting as chest wall tumors. ThoracSurg Sci. 2006 Feb 14;3: Doc01.

3. Pairolero PC, Arnold PG. Chest wall tumors. Experience with 100 consecutive patients. J Thorac Cardiovasc Surg. 1985 Sep;90(3):367-72.

4. Tauro, L. F., Ramesh, H. C., Shindhe, V. V., Hegde, B. R., Aranha, A., Rai, P. M., Jayakrishna. Primary bone lymphoma presenting as chest wall mass. Indian Journal of Thoracic and Cardiovascular Surgery, 2007; 23(4): 253-255. https://doi. org/10.1007/s12055-007-0052-3
5. King RM, Pairolero PC, Trastek VF, Piehler JM, Payne WS, Bernatz PE.Primarychest wall tumors: factors affecting survival. Ann Thorac Surg. 1986 Jun; 41 (6):597-601.

6. Gonfiotti A, Santini PF, Campanacci D, Innocenti M, Ferrarello S, Caldarella A, Janni A. Malignant primary chest-walltumours: techniques of reconstruction and survival. Eur J Cardiothorac Surg. 2010 Jul;38(1):39-45. doi: 10.1016/j.ejcts. 2009. 12.046. Epub 2010 Feb 24.

7. Sabanathan S, Salama FD, Morgan WE, Harvey JA. Primary chest wall tumors. Ann Thorac Surg. 1985 Jan;39 (1):4-15.

8. Anderson, B. O., \& Burt, M. E. Chest wall neoplasms and their management. The Annals of Thoracic Surgery. 1994;14975(94)91691-8.https:// doi. org/10.1016/0003.

9. Graeber, G. M., Snyder, R. J., Fleming, A. W., Head, H. D., Lough, F. C., Parker, J. S., ... Brott, W. H. Initial and long-term results in the management of primary chest wall neoplasms. Annals of Thoracic Surgery,1982; 34(6), 664-673. https://doi.org/10.1016/S0003-4975(10)60906-X

10. Threlkel JB, Adkins RB. Primary chest wall tumors. AnnThoracSurg 1971; 11:pp 450 -9.

11. Cavanaugh DG, Cabellon S Jr, Peake JB. A logical approach to chest wall neoplasms. Ann Thorac Surg. 1986 Apr;41(4):436-7.

12. Incarbone M, Pastorino U. Surgical treatment of chest wall tumors. World J Surg. 2001 Feb;25 (2):218-30.

13. Stelzer P, Gay WA Jr. Tumors of the chest wall. SurgClin North Am. 1980 Aug; 60(4): 779-91.

14. Hodgson, D. C., Tsang, R. W., Pintilie, M., Sun, A., Wells, W., Crump, M., \&Gospodarowicz, M. K. Impact of chest wall and lung invasion on outcome of stage I-II Hodgkin's lymphoma after combined modality therapy. International Journal of Radiation Oncology Biology Physics, 2003;57(5), 1374-1381. https://doi.org/10.1016/ S0360-3016(03)00765-X

\section{How to cite this article?}

Konwar N, Dutta A, Sharma A, Saikia P. Case report of a rare case of Non-hodgkin Lymphoma presenting as sternal mass. Int J Med Res Rev 2017;5(11):949-951.doi:10.17511/ijmrr. 2017.i11.05 